\title{
ANALYSIS OF S-SPECIFIC PROTEINS IN STIGMA OF BRASSICA OLERACEA L. BY ISOELECTRIC FOCUSING
}

\author{
TAKESHI NISHIO and KOKICHI HINATA \\ Faculty of Agriculture, Tohoku University, Sendai, Japan
}

Received 2.xii.76

\begin{abstract}
Summary
Polyacrylamide gel isoelectric focusing was used to study the buffer-soluble proteins of stigmatic homogenates of six S-allele genotypes in Brassica oleracea L. More than nine protein bands at higher $p \mathrm{H}$ in gels, being distinctly separated, were taken for the analysis of S-allele specificity. S-allele specificity was ascribable to a combination of the protein bands, and the parental bands were transmitted to the hybrid $\mathrm{F}_{\mathrm{I}} \mathrm{s}$. These protein bands appeared in the course of stigma maturation. No specific band pattern was observed in the leaf and seedling proteins, however. It is postulated that the $\mathrm{S}$-allele produces several fractions of proteins and S-allele specificity is expressed by a combination of the protein fractions.
\end{abstract}

\section{InTRODUGTION}

SINCE self-incompatibility has been shown to be genetically controlled by a multiple allelomorphic series of S-genes, a number of studies have been carried out to determine the nature of S-specific substances. In Brassica oleracea L., where self-incompatibility is determined sporophytically, Nasrallah et al. $(1967,1970)$ detected S-specific antigens in the stigmas by immunological technique, and suggested a unique band of basic proteins were ascribable to each $\mathrm{S}$-allele by electrophoretic analysis. The presence of such S-specific antigens in stigmas was also supported by Sedgley (1974).

In order to elucidate the nature of the specific proteins, separation of stigmatic extracts was attempted, using three methods of polyacrylamide gel electrophoresis.

\section{MATERIALS AND METHODS}

Six strains with different homozygous S-genotypes of Brassica oleracea L., described as $\mathrm{S}_{2}, \mathrm{~S}_{7}, \mathrm{~S}_{13}, \mathrm{~S}_{22}, \mathrm{~S}_{39}$ and $\mathrm{S}_{45}$, were kindly provided by Ir. N. P. A. van Marrewijk, Institute for Horticultural Plant Breeding, The Netherlands. Vegetatively propagated clones of each S-homozygote were raised for experimental use. Hybrid $\mathrm{F}_{1} \mathrm{~s}$ were also obtained between some of these homozygotes.

From the open flowers, 50 stigmas were homogenised by a mortar and pestle with $0 \cdot 1 \mathrm{ml}$ phosphate buffered saline $(0.01 \mathrm{M}$ phosphate buffer $p \mathrm{H} 7 \cdot 1$ plus $8.5 \mathrm{gm} / 1$ of $\mathrm{NaCl})$. The homogenate was centrifuged for $20 \mathrm{~min}$. at 10,000 r.p.m. and $20 \mu \mathrm{l}$ of the supernatant was introduced to each glass tube in every method of electrophoresis. The same technique was applied for the extraction of proteins from anthers, leaves and seedlings.

Protein separation was examined by polyacrylamide gel electrophoresis using three methods. The methods of Davis (1964) and of Reisfeld et al.

$38 / 3-\mathrm{H}$ 
(1962) were carried out under constant current, $2.5 \mathrm{~mA} /$ tube for 3 hours at $5^{\circ} \mathrm{C}$. The gels after running were stained with $0 \cdot 2$ per cent Coomassie Blue in ethanol-water-acetic acid $(45: 45: 10)$ for $45 \mathrm{~min}$. and then immersed in 7 per cent acetic acid to remove excessive dye.

When isoelectric focusing was applied according to Nakai (1970), a sample gel was laid on the $7 \cdot 5$ per cent acrylamide gel containing ampholine $(p \mathrm{H} 3 \cdot 5-10 \cdot 0$, LKB Co.), and the sample gel was faced to the anode side. Anode and cathode vessels were filled with $0.02 \mathrm{M} \mathrm{HCl}$ and $0.02 \mathrm{M}$ ethylenediamine, respectively. Electrophoresis was carried out under constant voltage, $200 \mathrm{~V}$, for 3 hours at $5^{\circ} \mathrm{C}$. The gels after running were immersed in 12.5 per cent trichloro-acetic acid for one night, and washed in 7 per cent acetic acid 4-5 times to remove ampholine. After being stained with the same solution as used in the other electrophoresis, they were de-stained with ethanol-water-acetic acid (25:65:10), and then kept in 7 per cent acetic acid.

To estimate $p \mathrm{H}$ values in different parts of the column, a gel column that was not stained, was cut into sequential pieces $5 \mathrm{~mm}$ in length. Five pieces at a comparable site of the five gels were immersed together into $5 \mathrm{ml}$ distilled water for 24 hours and the $p \mathrm{H}$ values of the water were measured.

Isozymes of esterase, acid phosphatase and peroxidase in stigmas were also examined by isoelectric focusing. Esterase activity was detected by $\alpha$-naphtyl acetate and Fast Blue RR salt at $p \mathrm{H} 7 \cdot 0$ (Nakai, 1970); acid phosphatase by disodium $\alpha$-naphtyl phosphate and Fast Garnet GBC salt at $p \mathrm{H} 5.0$ (Nakai, 1973); and peroxidase by $o$-dianisidine at $p \mathrm{H} 4.3$ and hydrogen peroxide at $p \mathrm{H} 6 \cdot 5$ (Yamamoto and Momotani, 1971).

\section{Results}

Numerous protein bands were separated by the Davis method, but no discernible difference was observed between four homozygotes of S-alleles. Using the method of Reisfeld et al., more than four bands were detected clearly, and their banding patterns were found to be different for each tested

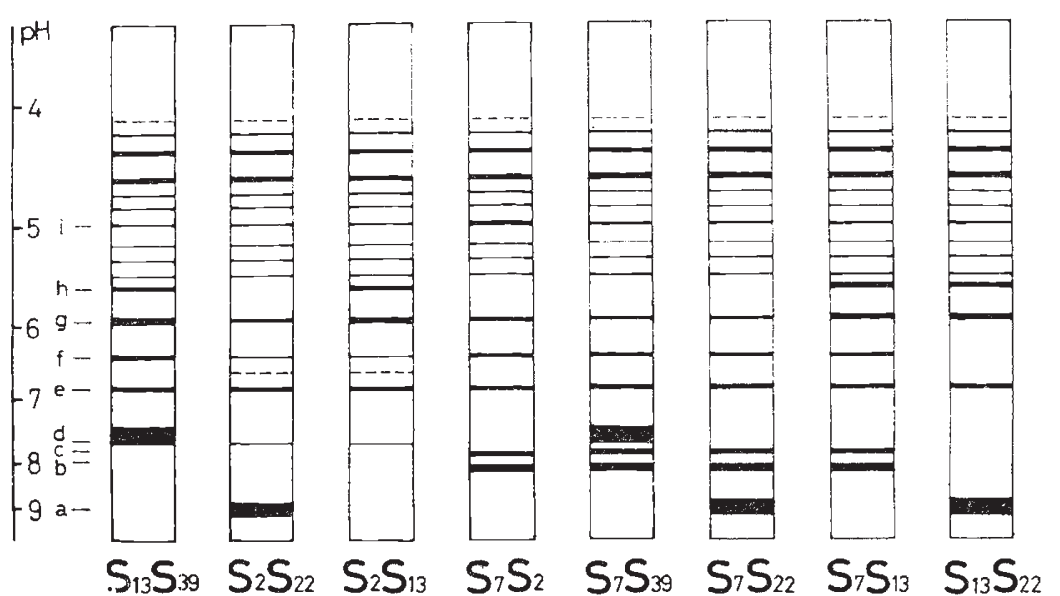

FIG. 3.-Diagrammatic representation of the band patterns of S-heterozygotes by isoelectric focusing. 
S-homozygotes (plate I, fig. 1). These results agree well with those of Nasrallah et al. (1970).

Isoelectric focusing from stigmatic extracts revealed the presence of numerous bands, ranging from $p \mathrm{H} 4$ to $p \mathrm{H} 9$. Bands at higher $p \mathrm{H}$ region were distinctly separated and their pattern showed genotype specificity as presented in plate I, fig. 2. The bands were tentatively named as $a, b, c$, etc. from the basic side of the column. The $S_{39}$ homozygous plant, for

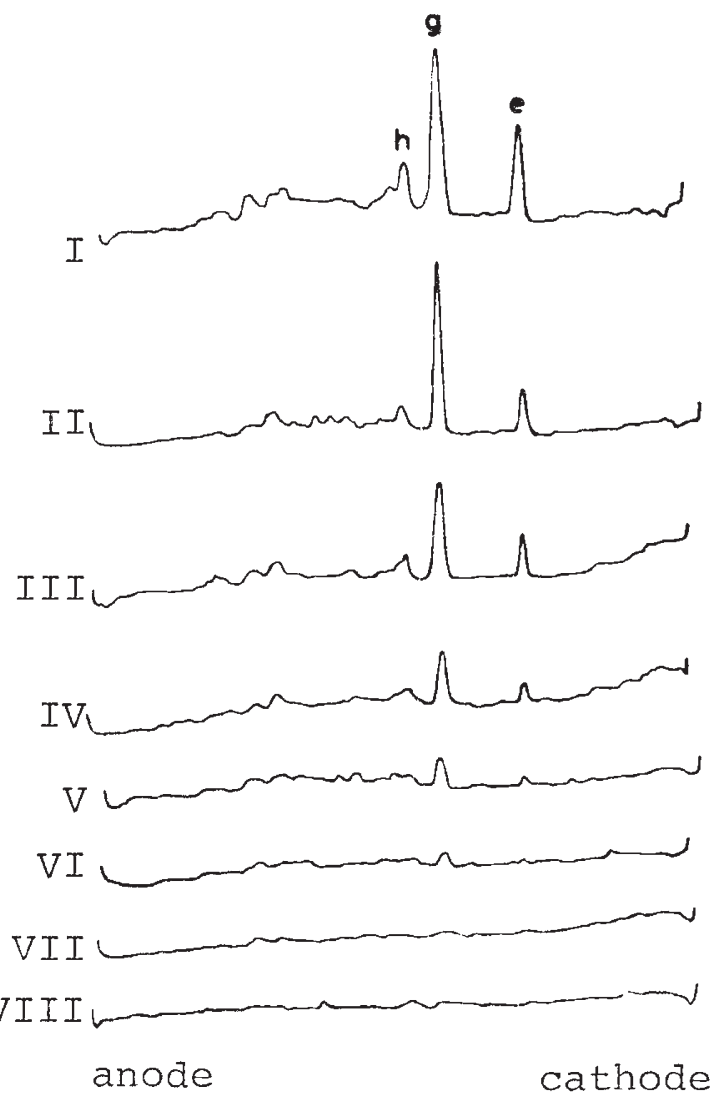

FIG. 4.-Densitometry of the band patterns of young and mature stigmas in $\mathrm{S}_{13}$ homozygotes. The names of bands, $e, g$, and $h$, correspond to those presented in fig. 2. Mature stigmas taken from open flowers were shown as I, and the youngest stigmas (VIII) were expected to be 7 days before blooming.

example, had $d, e, f, g$, and $i$ bands, while $\mathrm{S}_{13}$ had $e, g, h, i$, and trace $d$, etc. The band $e$ was observed in every homozygote. So far, in the six strains examined, all the S-homozygotes were differentiated by the combination of these bands of basic proteins.

Stigmas of eight hybrid $\mathrm{F}_{1} \mathrm{~s}$ between some of S-homozygotes were also analysed by the isoelectric focusing. In general, the band patterns of the $F_{1} s$ were the combination of both the parents (fig. 3). Two exceptional cases were however, recorded in hybrids $\mathrm{S}_{7} \mathrm{~S}_{2}$ and $\mathrm{S}_{13} \mathrm{~S}_{22}$ which showed the absence of $d$ and $f$ band, respectively. 
It is known in Brassica that S-allele specificity appears in mature stigmas but not young ones (Gonai and Hinata, 1971). The basic proteins of stigmas were compared between young and old. Since the flowers bloom from the basal part of a raceme to the terminal part, flower buds were collected along each raceme, and divided into eight groups, I-VIII, according to their position on the raceme. The group I represented open flowers and the group VIII had the youngest buds, which were expected to be 7 days before blooming. The number of stigmas per gel tube was equal in all groups. Stained tubes were measured by densitometer at $650 \mathrm{~nm}$. Specific bands of $\mathrm{S}_{13}, e, g$, and $h$, were clearly observed in the group I but not in the group VIII (fig. 4). The concentration of the specific bands increased rapidly in the bud stigmas of 2-3 days before blooming. Similar evidence of the appearance of specific antigens in mature stigmas has been presented earlier by immunological analysis (Nasrallah, 1974). Extracts from anthers, leaves and seedlings of the homozygotes were also analysed by the isoelectric focusing, but genotype-specific differences were not recognised, so far.

An experiment was conducted to study the isozymes of three enzymes, esterase, acid phosphatase, and peroxidase by isoelectric focusing. So far as the zymograms of four S-homozygotes were concerned, zymogram patterns were similar between them, and the sites of the enzyme activities were found to be different from that of specific protein bands.

\section{Discussion}

Basic protein fractions in stigmas have been shown to be S-specific by Nasrallah et al. (1967, 1970, 1974) using immunological and electrophoretic analysis. They were able to ascribe a unique electrophoretic band to each of the genotypes, $\mathrm{S}_{1} \mathrm{~S}_{1}, \mathrm{~S}_{2} \mathrm{~S}_{2}$ and $\mathrm{S}_{3} \mathrm{~S}_{3}$. Using different material, comparable electrophoretic patterns have been demonstrated in the present experiment by the method of Reisfeld et al. By this method the different bands were found to be located so close to each other, that some difficulty was experienced in the precise identification of band patterns between genotypes. The same stigmatic extracts were, therefore, subjected to the isoelectric focusing analysis.

With the present technique, the bands in the basic portion of gels were well separated, and the location of each band could be compared between S-homozygotes. S-allele specificity was ascribable to a combination of the bands and the parental combinations of protein bands appeared in the hybrid $\mathrm{F}_{1} \mathrm{~s}$. Further studies to relate the band patterns and the dominance relationships of the $\mathrm{S}$-alleles are in progress.

The running distances of protein fractions in the polyacrylamide gel isoelectric focusing depend on the isoelectric point of the fractions and on their molecular sizes. The isoelectric points of the fractions are, therefore, said to be equal to or higher than the $p \mathrm{H}$ values indicated by the location in the gels. The protein bands under analysis can be inferred to be basic proteins.

There is the possibility that these protein bands are not S-allele specific but are products of the genetic backgrounds of the S-homozygotes. Similar patterns of zymograms were, however, found in stigmas of different Shomozygotes for esterase, acid phosphatase, and peroxidase. No discernible specificity was found in leaf and seedling proteins of different S-homozygotes 

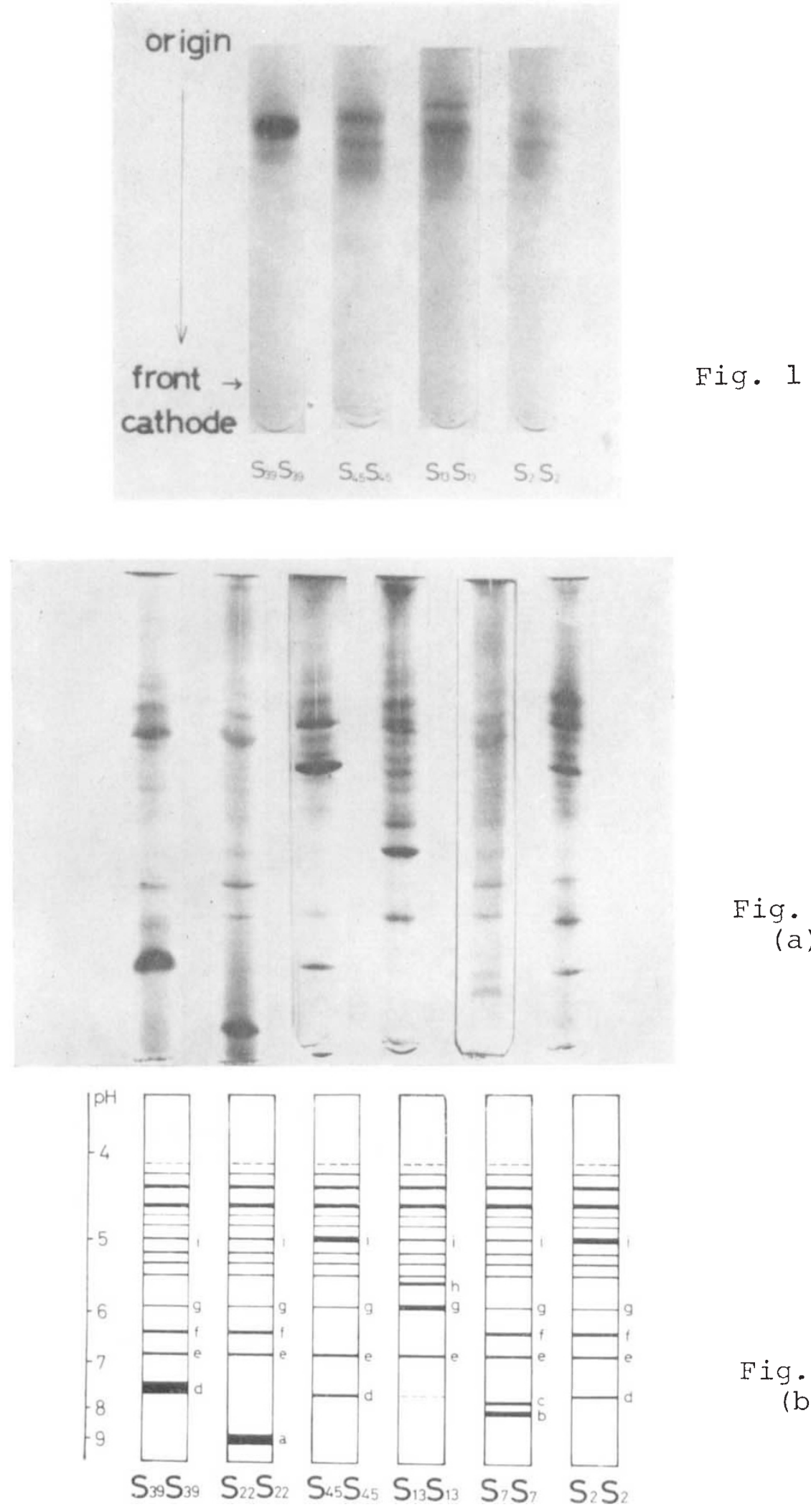

Fig. 2

(a)

PLATE I, Fig. 1.-Electrophoretic separation of the proteins from the stigmatic homogenates of different S-homozygotes by the method of Reisfeld et al. (1962).

Plate I, FIG. 2.-Electrophoretic separation (a) and its diagrammatic representation (b) of the stigmatic proteins of different $\mathrm{S}$-homozygotes by isoelectric focusing. The bands were tentatively named $a, b, c$, etc. from the basic terminal of the gels. 
by the isoelectric focusing. It may be inferred therefore that background of the material was not so different between S-alleles. The protein bands focused in the present method appear in the course of the maturation of stigmas and the time of appearance coincided with the phenotypic expression of self-incompatibility (Gonai and Hinata, 1971). The balance of evidence suggests, therefore, that some, if not all, of the fractions revealed by the isoelectric focusing are directly concerned with the specificity of S-alleles.

Lewis (1960) showed that in Prunus the S-allele is composed of, at least, two cistrons. From his studies of species crosses in Nicotiana, Pandey (1969) proposed that $\mathrm{S}$-alleles have a complex nature. If it is accepted that the $\mathrm{S}$-allele produces several proteins and that $\mathrm{S}$-allele specificity is expressed by a combination of the proteins, it can be postulated that new S-specificity is generated from intra $\mathrm{S}$-allele recombination.

Generation of new S-alleles during inbreeding has been reported in Trifolium pratense (Denward, 1963), in Nicotiana bonariensis (Pandey, 1970), and in Lycopersicum peruvianum (De Nettancourt et al., 1971). The suggestion that a new S-allele can be generated by the recombination of old S-alleles was first made by Fisher (1961) in order to explain the variability of S-alleles. The present results may provide experimental evidence for this line of argument.

These observations will be elaborated much more by further studies on segregating offspring and on the physiological role of the protein fractions.

Acknowledgments. - The authors are indebted to Prof. S. Tsunoda, Tohoku University, for valuable advice and encouragement, and to Dr S. Prakash, Indian Agricultural Research Institute, for his kind advice in the preparation of the manuscript. Thanks are also due to Dr A. J. Bateman for his kindness in critical reading and in correcting the manuscript.

\section{REFERENGES}

DAvis, B. J. 1964. Disc electrophoresis. II. Method and application to human serum proteins. Ann. N.Y. Acad. Sci., 121, 404-427.

DENWARD, T. 1963. The function of the incompatibility alleles in red clover (Trifolium pratense L.). III. Changes in the S-specificity. Hereditas, 49, 285-329.

Fisher, R. A. 1961. A model for the generation of self-sterility alleles. F. Theoret. Biol., 1, $411-414$.

GONAI, H., AND HINATA, K. 1971. Growth of pistils in relation to phenotypic expression of self-incompatibility in Brassica. Japan 7. Breeding, 21, 137-142.

LEWIS, D. 1960. Genetic control of specificity and activity of the $\mathrm{S}$ antigen in plants. Proc. Roy. Soc. B, 151, 468-477.

NAKAI, y. 1970. Esterase isozymes in germinating seed of Brassica and Raphanus. Japan. $\mathcal{F}$. Breeding, 20, 75-81.

Nakar, y. 1973. Isozyme variations in Aegilops and Triticum. II. Esterase and acid phosphatase isozymes studied by the gel isoelectrofocusing method. Seiken Ziho, 24, 45-73.

NASRALlAH, M. E. 1974. Genetic control of quantitative variation in self-incompatibility proteins detected by immunodiffusion. Genetics, 76, 45-50.

NASRAllaH, M. E., BARBER, J. T., AND WALlace, D. H. 1970. Self-incompatibility protein in plants: detection, genetics and possible mode of action. Heredity, 25, 23-27.

NASRAllah, M. E., AND WAllace, D. H. 1967. Immunogenetics of self-incompatibility in Brassica oleracea L. Heredity, 22, 519-527.

NETTANGOURT, D. DE, ECOGHARD, R., PERQUIN, M. D. G., DRIFT, T. VAN DER, AND WESTERHOF, W. 1971. The generation of new $\mathrm{S}$ alleles at the incompatibility locus of Lycopersicum peruvianum Mill. Theor. EP Appl. Genet., 41, 120-129.

PANDEY, K. K. 1969. Elements of the S-gene complex. V. Interspecific cross-compatibility relationships and theory of the evolution of the $\mathrm{S}$ complex. Genetica, 40, 447-474.

PANDEY, K. K. 1970. New self-incompatibility alleles produced through inbreeding. Nature, 227, 689-690. 
REISFELD, R. A., LEWis, V. J., AND WILlIAMS, D. E. 1962. Disk electrophoresis of basic proteins and peptides on polyacrylamide gels. Nature, 195, 281-283.

SEDGLEY, M. 1974. Assessment of serological techniques for S-allele identification in Brassica oleracea. Euphytica, 23, 543-551.

YAMAMOTO, T., AND MOMOTAN, Y. 1971. Separation and staining procedure of isoperoxidase by gel-electrofocusing. Chemical Regulation of Plants, 6, 187-189 (in Japanese). 